\title{
Mineralogic Characterization and Petroleum Potential of Clays (Shales) of the N'Kapa Formation (Paleocene-Eocene) in the Douala Sedimentary Sub-basin (South-West Cameroon)
}

\author{
Paul Lambert Kenfack ${ }^{1 *}$, Pierre Ricard Njike Ngaha1, Georges Emmanuel Ekodeck², \\ Gabriel Ngueutchoua ${ }^{2}$ \\ ${ }^{1}$ Faculty of Sciences, Department of Earth Sciences, University of Dschang, Dschang, Cameroon \\ ${ }^{2}$ Faculty of Science, University of Yaounde I, Yaounde, Cameroon \\ Email: "paulambertini@gmail.com
}

Received May 20, 2012; revised June 23, 2012; accepted June 30, 2012

\begin{abstract}
The aim of this research work was to report a facies analysis of the N'Kapa formation, identified the clay minerals present in those facies and evaluate their oil potential. For that to be done, Lithostratigraphic descriptions were performed on three natural outcrops chosen in three different localities of the northern border of Douala sedimentary basin. Ten shaly samples were then collected on those outcrops and submitted to X ray diffraction and Rock-Eval pyrolysis. Lithologically, the N'Kapa formation is made up of dark to grey shales and fine to coarse sandtones. The mineralogic content of the shales is made up of Kaolinite, dickite, low quartz and vaterite. Those shaly facies present high amount of immature organic matter (average TOC content around 2\%). The petroleum potential is fair to poor (average S2 for all the samples around $3.33 \mathrm{mg} \mathrm{HC/g}$ of rock) though some samples (M1 and M2) presenting a good petroleum potential up to $6.62 \mathrm{~kg} \mathrm{HC} / \mathrm{t}$ of rock and $6.44 \mathrm{~kg} \mathrm{HC} / \mathrm{t}$ of rock respectively. They have undergone a low degree of diagenesis (early to burying diagenesis). This is evidenced by the predominance of kaolinite and dickite, low quartz and vaterite which are minerals stable at low temperature.
\end{abstract}

Keywords: Mineralogy; Organic Matter; Petroleum Potential; N’Kapa Formation; Douala Sub-Basin

\section{Introduction}

The Cameroon Atlantic basin located in the Gulf of Guinea is one of the West African coastal basins. It comprises two major basins: The Douala-Kribi/Campo basin and the Rio Del Rey one.

However, these two sedimentary units are separated in onshore by the volcanic massif of Mount Cameroon form only one sedimentary basin in their offshore extension from which the name coastal atlantic basin of Cameroon is deduced. The Douala/Kribi-Campo (Figure 1) basin is in its turn subdivided into two sub-basins: the KribiCampo sub-basin in the south and the Douala sub-basin, the northern component.

Owing to the economic potential of this area, several studies have been carried out by scientist and petroleum industry, leading to the typification and the stratigraphy of the deposits. (Amonst: [1-19]. These works were based on many important field campaigns motivated by

\footnotetext{
"Corresponding author.
}

the scientific interest, but also and predominantly the economic interest of the facies. Reference here is made to oil and natural gas.

All those works for the most part were very globalizing, ignoring the specificities of each sector of the basin. However, the structural dynamics that led to the establishment of the sedimentary basin of Douala Kribi/ Campo like other basins of the West African coast has resulted in the sequence variability of deposits by sector considered. Moreover, many of the works are unpublished because of the known confidentiality characterizeing the oil research domain.

Indeed, the establishment of the Douala sub-basin, linked to the gradual opening of the South Atlantic, resulted in a diachronism of deposits from South to North. Another consequence of this was a temporal and spatial variation of sedimentary environments along the West African coast and consequently facies characteristics. This situation does not permit to easily extrapolate results obtained on one sector to another. Reason why 


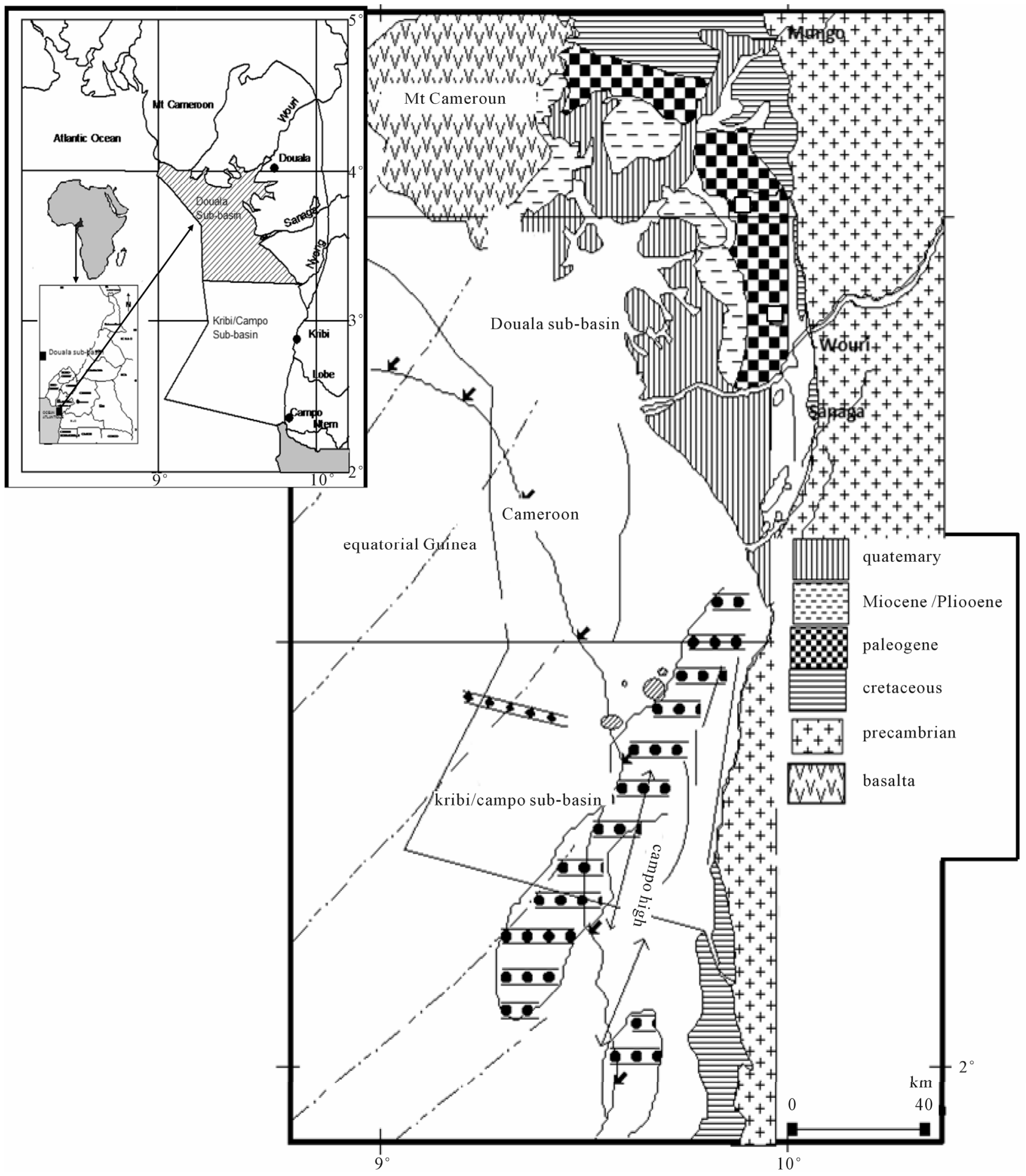

Figure 1. Location map of Cameroon (West Africa) and outlines of the Douala and Kribi/Campo sedimentary sub-basins. (Modified from SNH (1999)).

Cameroonians sedimentary geologists and foreigners decided to conduct research program in each sector of the Cameroon Atlantic basin. It is in this context that Ntamak et al since few years has being developing an important scientific production in the Kribi-Campo sub-basin, [19] has carried out a research topic on the palynostratigraphy of the Cretaceous facies in the eastern border of the Douala sedimentary sub-basin. No specific work had yet been carried on the Tertiary sedimentary facies of the northern part of the Douala sedimentary sub-basin. 
Moreover, as mentioned above, there is no published data existing concerning petroleum potential of this subbasin.

The purpose of this article is 1) to report a comprehensive facies analysis of the Tertiary deposits cropping out in the North of the Douala sub-basin; 2) to identify the minerals present in shaly facies; 3 ) to evaluate the oil potential of the clay facies and 4) to discuss and interpret all these in terms of level of diagenesis and oil productivity.

\section{Geological Setting}

The Douala sedimentary basin stretches on the South coast of Cameroon both onshore and offshore between latitude $3^{\circ} 03^{\prime} \mathrm{N}$ and $4^{\circ} 06^{\prime} \mathrm{N}$ and longitude $9^{\circ} 00^{\prime}$ and $10^{\circ} 00^{\prime} \mathrm{E}$, covering a total surface area of $12,805 \mathrm{~km}^{2}$ (Figure 1). It has a crescent shape starting from the south-eastern border of Mount Cameroon where the onshore part is about $70 \mathrm{~km}$ wide (In the N20E direction) and extend throughout the atlantic coast with a gradual decrease in width of the onshore part towards the South up to Londji (North of Kribi). It is limited to the South by the Cameroon volcanic line, to the East by the late Proterozoic Pan-African belt. The southern limit is more difficult to define. The onshore part of the Douala sub-basin has a trapezoic shape and covers a total surface area of about $6955 \mathrm{~km}^{2}$ while the offshore part covers an area of about $5850 \mathrm{~km}^{2}$.

In a chronological aspect, the history of the Douala sedimentary sub-basin presents three major stages:

1) All begins with the Precambrian phase of cratonisation, granitisation and sedimentation followed by the pan-african orogenesis.

2) After this Cambrian phase, the geology of the Douala sub-basin is only known starting from the lower Cretaceous during which epicontinental sedimentation begins to field an afro-brazilian depression, site of the future atlantic basin of Cameroon. Sediments whose age varies from Cretaceous to Pliocene are discordant on the Precambrian pan-african basement (Figure 2). The sedimentation was accompanied by Plutonism (Cenomanian)

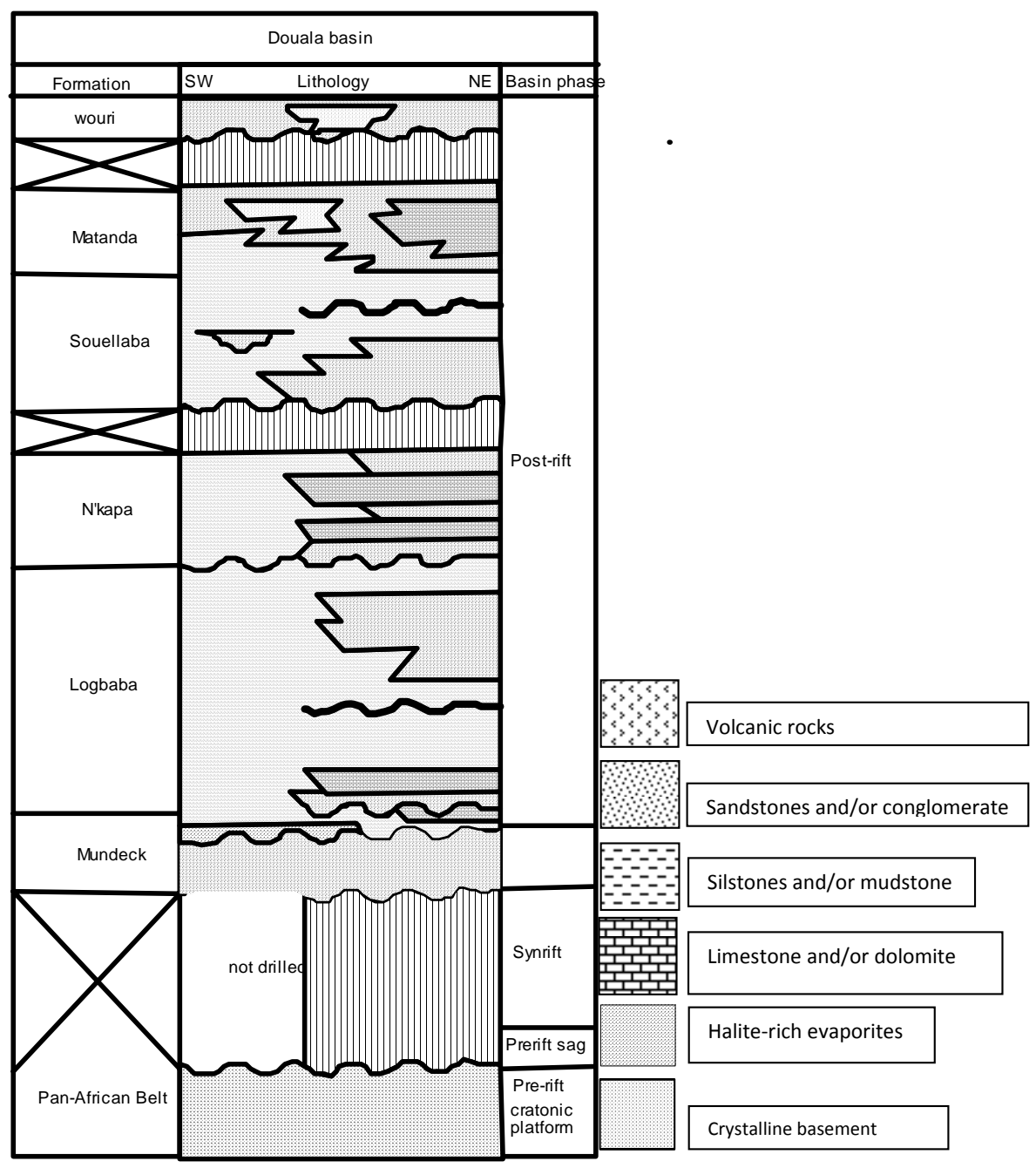

Figure 2. Tectono-lithostratigraphy of the Douala sub-basin (compiled from [20,42]). 
And volcanism (Miocene) which products cover sediments in some area (e.g. Volcanic products of Mount Cameroon).

The complete tectono-lithostratigraphic sequence based on oil exploration seismic and drill data offshore comprises six formations from the barremian-Aptian to present deposited during the pre-rift, syn-rift, rift-drift and post-rift basin phases (Figure 2).

1) Pre-rift phase: Prior to the rifting of the Afro-American plate, Jurassic continental sediments were deposited in an afro-brasilian depression, an intracratonic sag basin that extended over the Gabon and Douala basins[20].

2) Rifting phase (Jurassic-Barremian): The stratigraphic sequence here appears to be controlled by listric faulting and associated roll over anticlines [21].

3) The syn-rift phase was responsible for the fracture pattern closely controlled by inherited structures of the Precambrian basement. This phase is characterized by an intensive erosion activity of the highlands and deposition in graben previously formed. In the Kribi/Campo subbasin, these units named Lower Mundeck by [22] are exposed on the sea bottom or are shallowly buried by younger sediments [23]. They are made up of conglomerates, conglomeratic sandstones, organic matter-rich dark marls interbedded with thin limestones and black to dark grey shales. In the Douala sub-basin, Aptian syn-rift deposits overlie a narrow bench of attenuated continental basement [8,24-26]. Here, they are referred to as the Upper Mundeck Formation (Figure 2). The section drilled of the upper Mundeck Formation contains faunas which record the first marine incursion ([8] Reyre, 1966; [23,26, 27]. Deposits are made up of continental polygenic conglomerates with arkosic sandstones cement showing rare interbedded ferruginous clay, an alternation of laminated silt or sand with black shales and arkosic medium grain sandstones. Their environments of deposition have been interpreted as ranging from terrestrial to lacustrine, through restricted to fully marine. Pre-Aptian syn-rift deposits and basement rocks have not been reached by drilling.

4) The rift-drift transition phase (mid-late Aptian).

This phase was marked by salt deposition and the transform direction resulting in a series of cross-faults which have segmented the rift structure [28]. Salt domes have been recognized thgrough seismic campaigns in the Kribi/Campo sub-basin. They are located over the major western bounding fault system of the Kribi/Campo high. They overlie the Mundeck Formation from which they are separated by a probably breakup unconformity [2931]. This suggests that salt was deposited in the final stage of continental rifting. In the Douala sub-basin, evidence of evaporites has not yet been well stated.

5) Post-rift phase (Albian-Present): Following salt deposition, post-rift sedimentation in the Douala basin was dominated by marginal to clastic sedimentation, with shallow water carbonate deposition occurring as sporadic build ups between the Albian and Paleocene. From Aptian to Turonian, the juvenile South Atlantic ocean was filled with anoxic bottom waters presumably caused by restriction of open ocean circulation and ponding of bottom waters between Walvis Ridge and Rio Grande Rise in the South, and equatorial fracture zone topography in the North [32-37]. This led to deposition of black shales in the deeper part of the basin, and an intermittent carbonate deposition on the margins, above the oxygen minimum zone $[25,31,38]$. Unrestricted ocean circulation is thought to have commenced in the Turonian, when the North and South atlantic gateways were joined. According to [29], the post-rift phase comprises three stages of drift:

a) The first one (Albian-Coniacian) is characterized by rotational fault blocks in the proximal part, salt movement $[21,39,40]$, and gravity sliding. These structures are linked to gravitational instability of the margin and the presence of salt. Sedimentologically, this phase is marked in the Douala basin by a major regression leading to the decrease of the sea level. The consequence was the erosion of the Lower Cretaceous sequence thereby creating a surface of unconformity with an irregular topography. The unconformity at the base of Upper Cretaceous was followed by the deposition of the Logbadjeck formation (Cenomanian-Campanian), the Logbaba formation (Cenomanian-Maastrichtians) and the Nkapa formation (Paleocene-Eocene).

b) The second drift phase named Drift II was a discrete drift one linked to regional tectonic episode. During this phase, original rift-related structures were inverted and the platform sedimentary section was folded [41]. The Santonian unconformity separating the first and second drift stages is recognized along the West African margin as a result of the uplift during the Cretaceous episode.

c) The third drift stage (Eocene) named drift III has been linked to gravity sliding caused by uplift in the Tertiary. The Uplift and erosional unconformity are dated to about 30 - 40 Ma. This phase in the Douala sedimentary basin was marked by deposition of the Souellaba formation (Oligocene), the Matanda formation (Miocene) and the Wouri formation (Pliocene-Pleistocene).

The area considered in this paper constitutes the northern border of the Douala sub-basin (Figure 1). It corresponds to a strip of terrain limited to the north by clayish sand of Senonian age, to the East by river Wouri, to the West by Mount Cameroon and in the South by the Wouri river mouth. The sedimentary series known here is of Tertiary age [42].

\section{Data Sets and Methods}

The study whose results are presented here took place in 
two main phases marking the approach chosen to achieve the goal:

\subsection{Fieldwork}

During this phase, lithostratigraphic investigations were carried out throughout the Tertiary formations in the northern part of the Douala sedimentary basin. As a result of these prospective campaigns, three outcrops were chosen as representative and selected for the study. Thus, after detailed description of the different lithofacies constituting each outcrop, lithostratigraphic columns were performed. This description allows identifiying some basic characteristics of the depositional environments. This phase ended with the collection of samples for analysis.

\subsection{Material}

Ten samples (K1, K2, K3, M1, M2, M3, M4, M5, F2 and F4) were collected from the dark to grey shales strata of the N'kapa formation. They were taken from three natural outcrops located in three localities. Kompina, Miang and Fiko (Figure 3) of the northern border of the Douala sedimentary basin.

\subsection{Laboratory Analysis}

1) X-ray diffraction (XRD)
The different clay minerals have been determined on four samples collected on the three outcrops. The Bragg's law has been used to determine the "diffraction peaks" by the following formula: $2 \mathrm{~d} \sin \theta=\mathrm{n} \lambda$. With $\mathrm{d}=$ spacings, that is the distance between two crystallographic planes, $\theta=$ angle of incidence of $\mathrm{X}$-rays, $\mathrm{n}=$ order of reflection, $\lambda=$ wavelength of $\mathrm{X}$-rays. The value of each peak characterizes a precise clay mineral.

2) Rock eval pyrolysis

Ten samples were collected from these outcrops, taking care to avoid weathered portions of the outcrop. The shaly samples were hard, thickly laminated, with texture indicative of low permeability, suggesting minimum risk of organic matter oxidization. In laboratory, the samples were reshaped using knife to eliminate surfaces that could be affected by alteration.

The samples were first treated with a mixture of water and liquid soap, washed with a column of two sieves (125 $\mu \mathrm{m}$ and $800 \mu \mathrm{m}$ respectively) and then dried in a sweating room at $37^{\circ} \mathrm{C}$ during 24 hours. After drying the samples were sorted with a magnifying glass to remove the solid pollutants.

Total Organic Carbon (TOC, wt\%) was determined using a Rock éval 6 apparatus by combustion of $20 \mathrm{~g}$ of sample up to $600^{\circ} \mathrm{C}$ under inert atmospheric conditions (presence of nitrogen and hydrogen), without previous decarbonatation; the resulting $\mathrm{CO}_{2}$ was quantified by

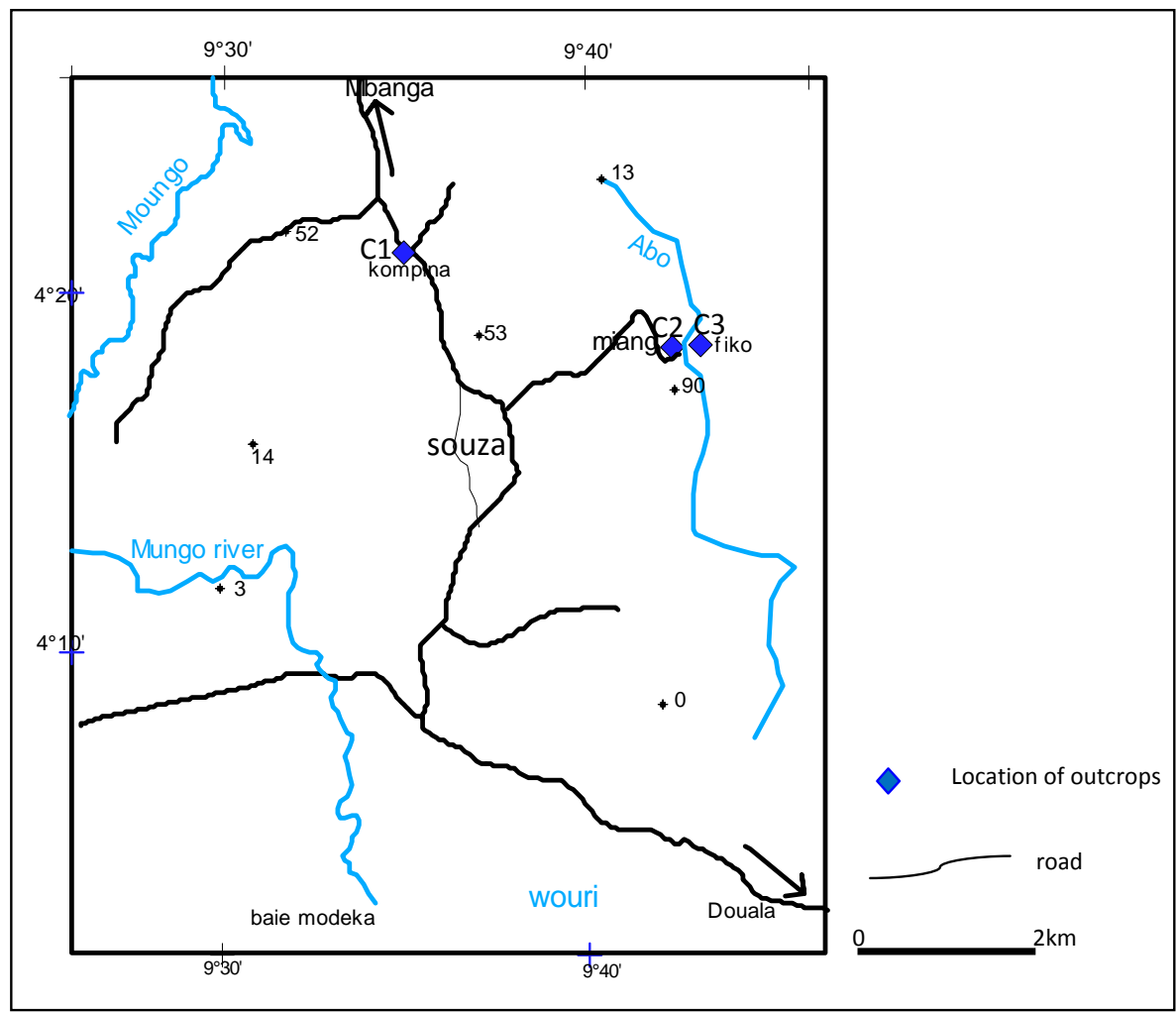

Figure 3. Map showing the location of the area studied, onshore northern Douala, and the studied outcrops. 
infrared detector. Calcium carbonate content $\left(\mathrm{CaCO}_{3}\right.$, wt\%) was determined using a calcimetric bomb by $\mathrm{HCl}$ digestion of $20 \mathrm{~g}$ of sample; the resulting $\mathrm{CO}_{2}$ was determined by pressure measurement.

Total Organic Carbon content (TOC, wt\%) is calculated by determining the difference between total carbon and carbonate carbon, assuming that all carbonate is pure calcite and represents the unique source of inorganic carbon. Informations on the type and thermal maturity of the organic matter were obtained using Rock-Eval pyrolysis with an Oil Show Analyser device under standard conditions (see all details about Rock-Eval pyrolysis and parameters in [44].

Hydrogen Index (HI, mg HC/g TOC), Tmax $\left({ }^{\circ} \mathrm{C}\right)$ and Petroleum Potential (PP, kg HC/t) were determined.

\section{Results and Interpretations}

\subsection{Facies Analysis: Lithostratigraphy}

Three outcrops among which one at kompina (C1), one at Miang (C2) and one at Fiko (C3) were used as the basis for the study. The description of the lithostratigraphic succession in these outcrops was carried out from the base to the top taking into consideration the following parameters: lithology, texture, thickness, and fossils content and sedimentary structures. The synthetic lithostratigraphical sections of each outcrop are presented in Figures 4-6. Some details characteristics of outcrops C1 and C2 are illustrated in Figure 7.

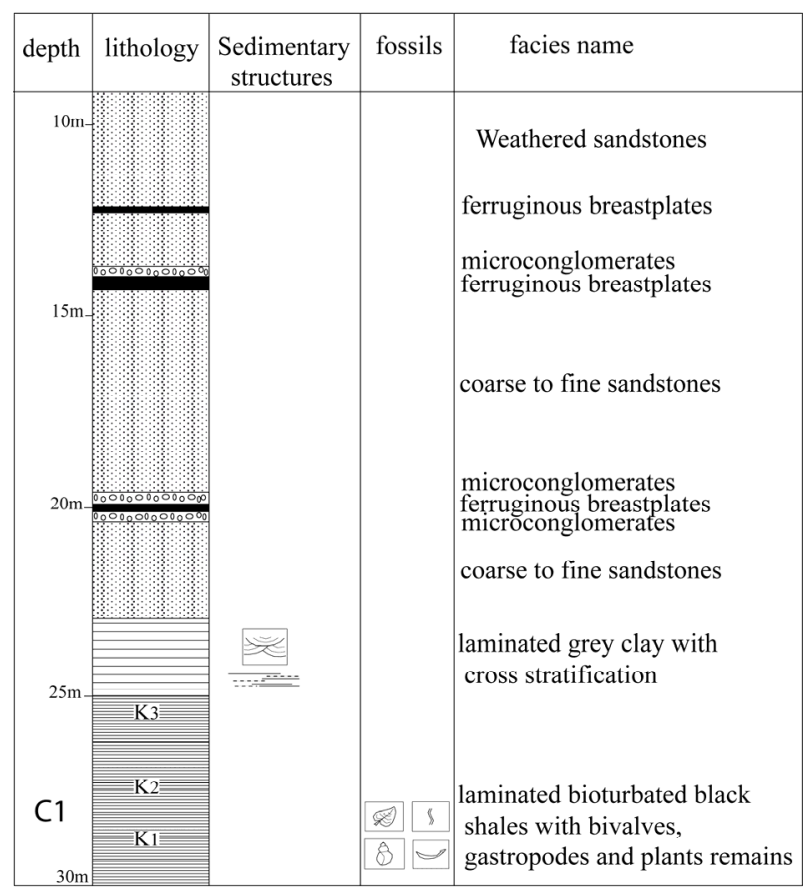

Figure 4. Lithostratigraphic section of outcrop C1 showing the stratigraphic position of the dark to grey shales and the investigated samples.

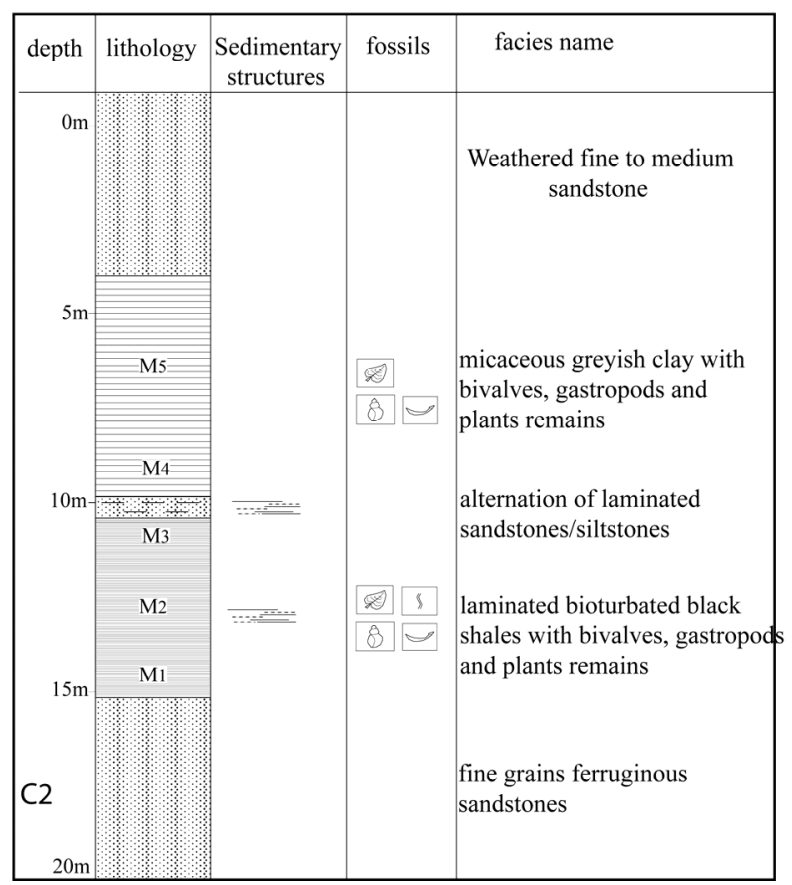

Figure 5. Lithostratigraphic section of outcrop C1 showing the stratigraphic position of the dark to grey shales and the investigated samples.

\begin{tabular}{|c|c|c|c|c|}
\hline depth & lithology & $\begin{array}{l}\text { Sedimentary } \\
\text { structures }\end{array}$ & fossils & facies name \\
\hline $10 \mathrm{~m}$ & & & & $\begin{array}{l}\text { fine to medium pelitic sandstones } \\
\text { sometimes arkosic }\end{array}$ \\
\hline $20 \mathrm{~m}$ & ( & & & $\begin{array}{l}\text { pelitic coarse sandstones with } \\
\text { blunted quartz grains and silts lens }\end{array}$ \\
\hline & 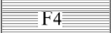 & & & micaceous (muscovite) black shales \\
\hline & F海棌湆 & & & $\begin{array}{l}\text { pelitic coarse sandstones with } \\
\text { blunted quartz grains }\end{array}$ \\
\hline $25 \mathrm{~m}$ & 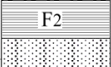 & & 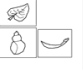 & $\begin{array}{l}\text { black shales with bivalves, } \\
\text { gastropods and plants remains }\end{array}$ \\
\hline $\mathrm{C} 3$ & & & & ferruginous finc sandstonc \\
\hline $30 \mathrm{~m}$ & & & & \\
\hline
\end{tabular}

Figure 6. Lithostratigraphic section of outcrop C1 showing the stratigraphic position of the dark to grey shales and the investigated samples.

\subsection{Results of X-Ray Diffraction Analyses}

The minerals found within the samples are: Kaolinite $\left(\mathrm{Al}_{2} \mathrm{Si}_{2} \mathrm{O}_{5}(\mathrm{OH})_{4}\right)$, Dickite $\left(\mathrm{Al}_{2} \mathrm{Si}_{2} \mathrm{O}_{5}(\mathrm{OH})_{4}\right)$, Vaterite $\left(\mathrm{CaCO}_{3}\right)$ 


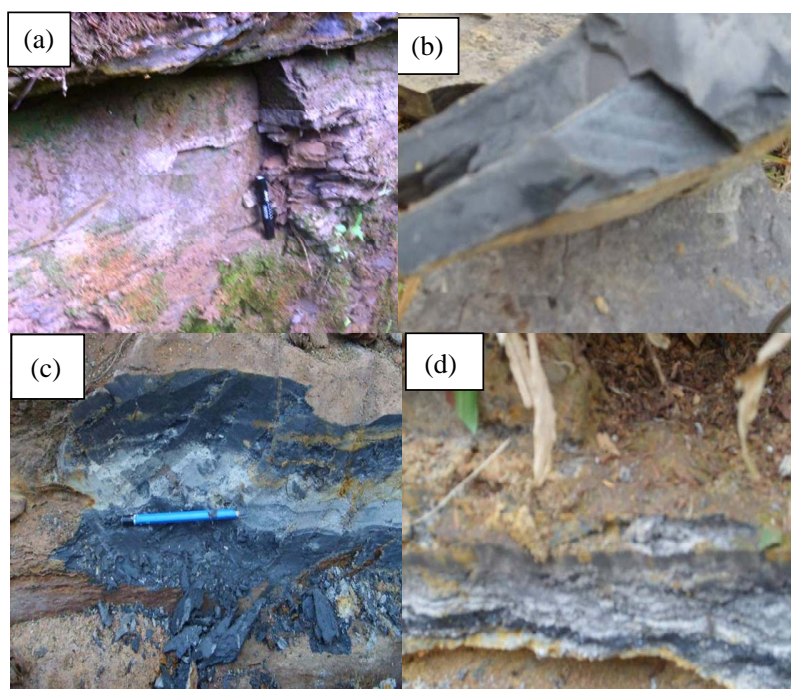

Figure 7. Shaly and silty facies of the Nkappa Formation cropping out at Kompina and Miang showing some sedimentary structures: (a) Massive dark clay of outcrop C1; (b) Leaves imprints in dark clay of outcrop C2; (c) Silty lens in dark clay of outcrop C2; (d) Alternation of silty and clay laminae in outcrop $\mathrm{C} 2$.

and low quartz.

Diffractogram showing the peaks of different clay minerals are presented in Figure 8.

\subsection{Organic Matter Analyses: Rock-Eval Pyrolysis}

Ten sedimentary rock samples were subjected to pyrolysis Rock-Eval 6 to determine the geochemical parameters of their organic matter. These samples come from outcrops of three distinct localities: Kompina (3 samples: K1, K2, and K3), Miang (5 samples: M1, M2, M3, M4 and M5) and Fiko (2 samples: F2 and F4).

\subsection{Samples from Outcrop C1}

Organic matter in these samples is sterile (poor) for sample K3, but there is a good concentration of organic matter for samples K2 and K3 (Table 1). Its petroleum potential (S2 varies between 0.27 and $2.94 \mathrm{mg} \mathrm{HC/g}$ of rock with an average of $1.63 \mathrm{mg} \mathrm{HC/g}$ rock) is globally poor. This dispersed immature organic matter is of type II and III (Figure 9), from terrestrial origin and consists of fragments of higher plants.

\subsection{Samples from Outcrop C2}

Samples of this outcrop have good accumulation of organic matter (TOC ranging from 1.07 to $4.42 \mathrm{wt} \%$ with an average of $2.72 \mathrm{wt} \%)$. This organic matter with a mean petroleum potential (samples M3 and M4) to good (samples M1 and M2) is immature (mean $\mathrm{T}_{\max }=412^{\circ} \mathrm{C}$ ). Samples of this outcrop have a globally dispersed organic matter of type II and III (Figure 9). This suggests that the organic matter contained in these samples is rather of terrestrial origin and consists of fragments of higher plants and sometimes of type IV. It is noticed the presence of non-native oil for samples M1 and M2, materialized by the high values of S1 and TPI in those samples (Table 2).

\subsection{Samples from Outcrop C3}

Samples of outcrop C3 have a good amount of organic matter of type II (Figure 9) for sample F2 and Type II for sample F4 with an average generation potential (average $\mathrm{S} 2=4.33 \mathrm{mg} \mathrm{HC} / \mathrm{g}$ rock). This organic matter is immature (mean $\mathrm{T}_{\max }: 417^{\circ} \mathrm{C}$ ) and shows traces of oil especially for sample F2 (Table 3).

Table 1. Geochemical parameters for samples of outcrop C1.

\begin{tabular}{|c|c|c|c|c|c|c|c|c|c|c|}
\hline Samples & $\begin{array}{l}\text { Depth } \\
\text { (m) }\end{array}$ & $\begin{array}{l}\mathrm{S} 1 \text { (mg HC/g } \\
\text { roche) }\end{array}$ & $\begin{array}{l}\mathrm{S} 2 \text { (mg HC/g } \\
\text { roche) }\end{array}$ & $\begin{array}{l}\mathrm{S} 3 \text { (mg } \mathrm{CO}_{2} / \mathrm{g} \\
\text { roche) }\end{array}$ & $\begin{array}{c}\operatorname{Tmax} \\
\left({ }^{\circ} \mathrm{C}\right)\end{array}$ & $\begin{array}{c}\mathrm{HI} \text { (mg HC/g } \\
\text { TOC) }\end{array}$ & $\begin{array}{c}\mathrm{OI}\left(\mathrm{mg} \mathrm{O}_{2} / \mathrm{g}\right. \\
\mathrm{TOC})\end{array}$ & $\begin{array}{c}\text { TPI } \\
(\mathrm{S} 1 / \mathrm{S} 1+\mathrm{S} 2)\end{array}$ & $\begin{array}{c}\text { TOC } \\
\text { (\% pds) }\end{array}$ & $\begin{array}{c}\text { MINC } \\
(\%)\end{array}$ \\
\hline K1 & 20 & 0.41 & 0.27 & 0.3 & 395 & 123 & 136 & 0,6 & 0,22 & 0,11 \\
\hline K2 & 25 & 0.4 & 1.69 & 0.66 & 411 & 86 & 34 & 0,19 & 1,95 & 0,15 \\
\hline K3 & 28 & 0.71 & 2.94 & 0.86 & 415 & 123 & 36 & 0,2 & 2,38 & 0,17 \\
\hline
\end{tabular}

Table 2. Geochemical parameters for samples of outcrop C2.

\begin{tabular}{ccccccccccc}
\hline Samples & $\begin{array}{c}\text { Depth } \\
(\mathrm{m})\end{array}$ & $\begin{array}{c}\mathrm{S} 1(\mathrm{mg} \mathrm{HC} / \mathrm{g} \mathrm{S} 2(\mathrm{mg} \mathrm{HC} / \mathrm{g} \\
\text { roche) }\end{array}$ & $\begin{array}{c}\mathrm{S} 3\left(\mathrm{mg} \mathrm{CO}_{2} / \mathrm{g}\right. \\
\text { roche) }\end{array}$ & $\begin{array}{c}\mathrm{T}_{\max } \\
\left({ }^{\circ} \mathrm{C}\right)\end{array}$ & $\begin{array}{c}\mathrm{HI}(\mathrm{mg} \mathrm{HC} / \mathrm{g} \\
\mathrm{TOC})\end{array}$ & $\begin{array}{c}\mathrm{OI}\left(\mathrm{mg} \mathrm{O}_{2} / \mathrm{g}\right. \\
\mathrm{TOC})\end{array}$ & $\begin{array}{c}\mathrm{TPI} \\
(\mathrm{S} 1 / \mathrm{S} 1+\mathrm{S} 2)\end{array}$ & $\begin{array}{c}\mathrm{TOC} \\
(\% \mathrm{pds})\end{array}$ & $\begin{array}{c}\mathrm{MINC} \\
(\%)\end{array}$ \\
\hline M5 & 7 & 0.16 & 1.24 & 1.36 & 410 & 70 & 77 & 0.12 & 1.76 & 0.15 \\
$\mathrm{M} 4$ & 9 & 1.48 & 3.8 & 0.37 & 416 & 355 & 34 & 0.28 & 1.07 & 0.15 \\
M3 & 11 & 0.41 & 2.08 & 3.33 & 413 & 67 & 107 & 0.16 & 3.12 & 0.26 \\
M2 & 13 & 2.05 & 6.44 & 1.55 & 412 & 199 & 48 & 0.24 & 3.23 & 0.25 \\
M1 & 15 & 2.8 & 6.62 & 1.74 & 409 & 150 & 39 & 0.3 & 4.42 & 0.27 \\
\hline
\end{tabular}




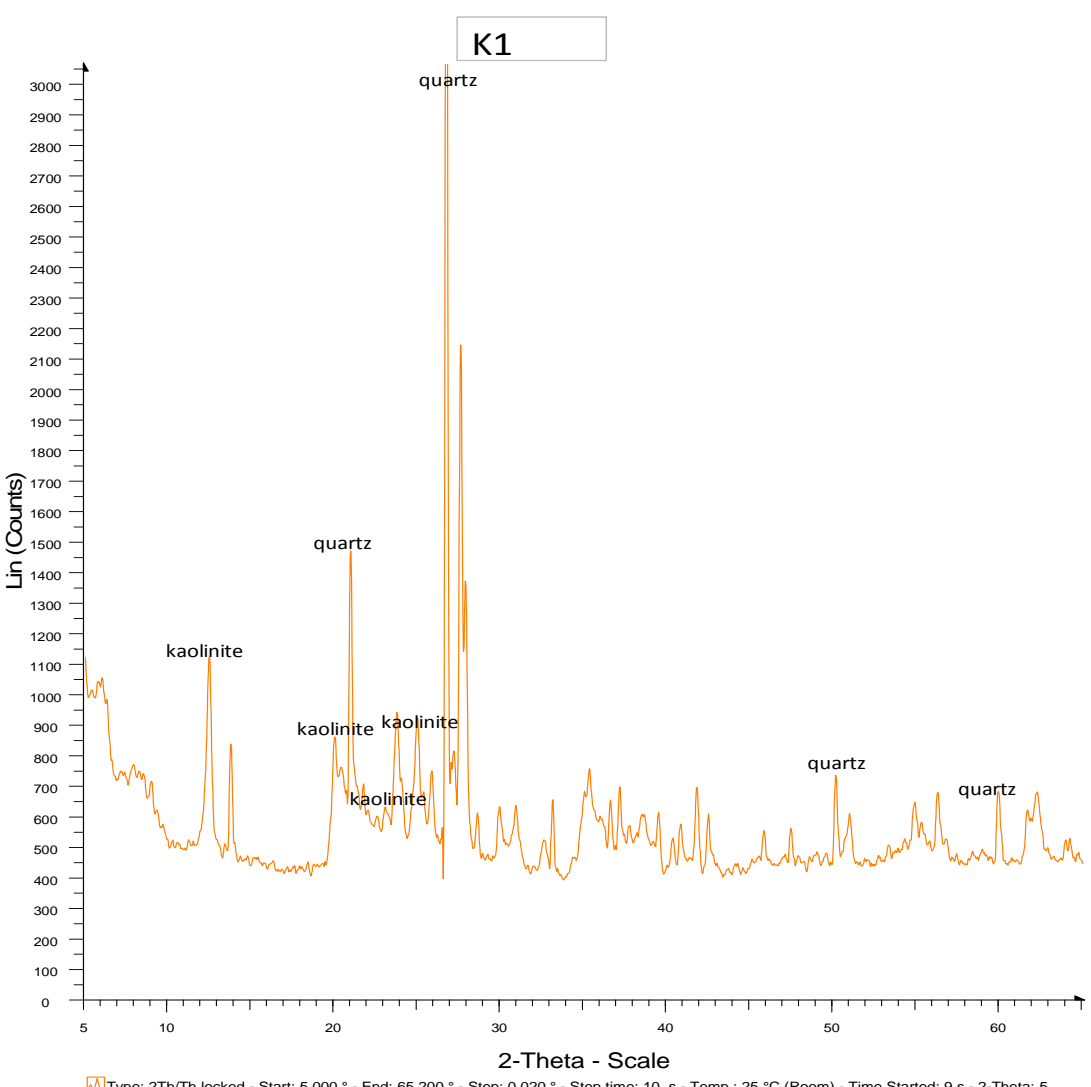

Operations: Smooth 0.150 | Fourier $20.000 \times 1$ | Strip kAlpha2 0.000 | Y Scale Mul 2.000 | Import

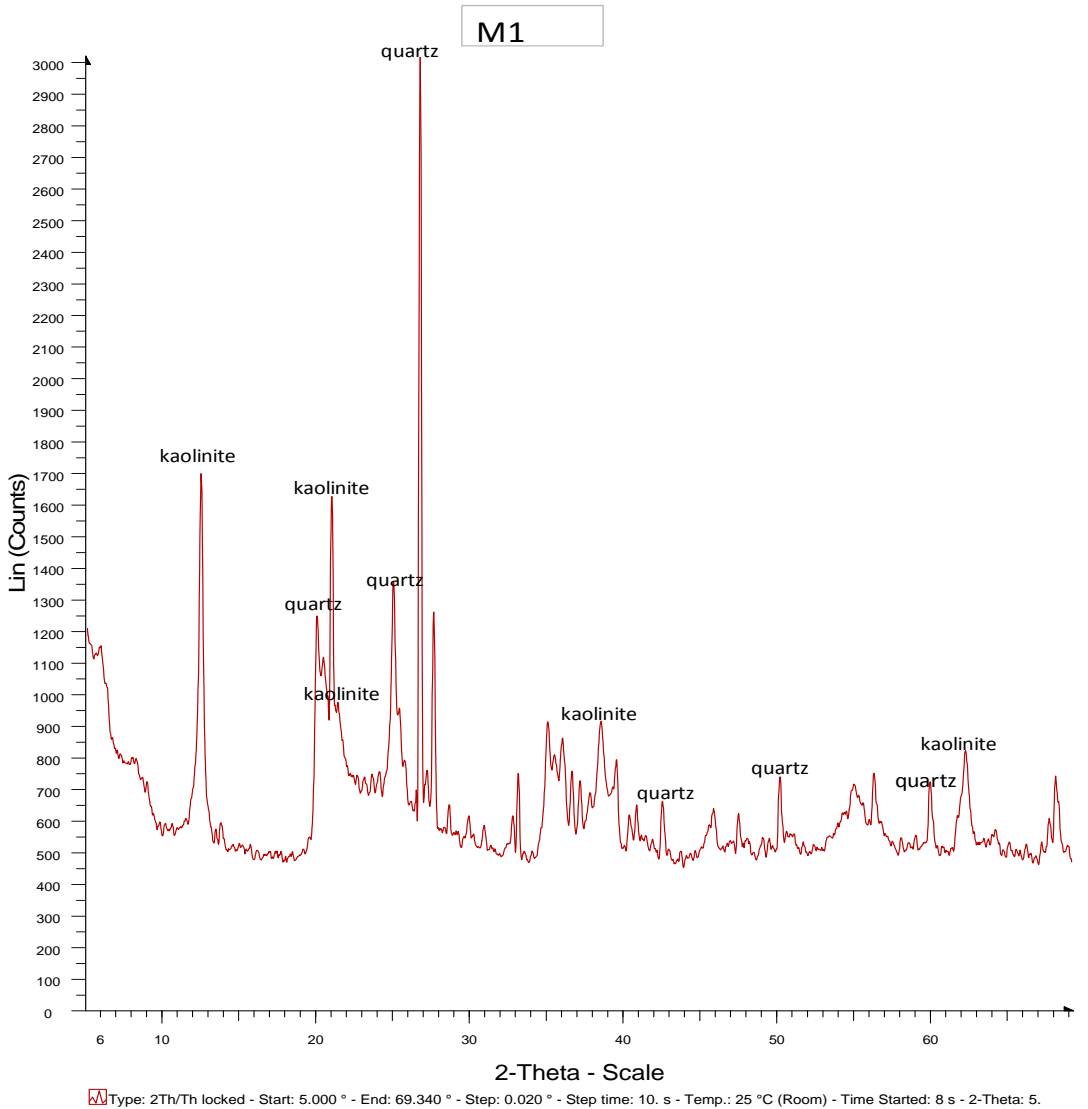

WType: 2 Th/Th locked - Start: $5.000^{\circ}$ - End: $69.340^{\circ}$ - Step: $0.020^{\circ}$ - Step time: $10 . \mathrm{s}$ - Temp.: $25^{\circ} \mathrm{C}$ (Room) - Time Started: $8 \mathrm{~s}$ - 2-Theta: 5 . 


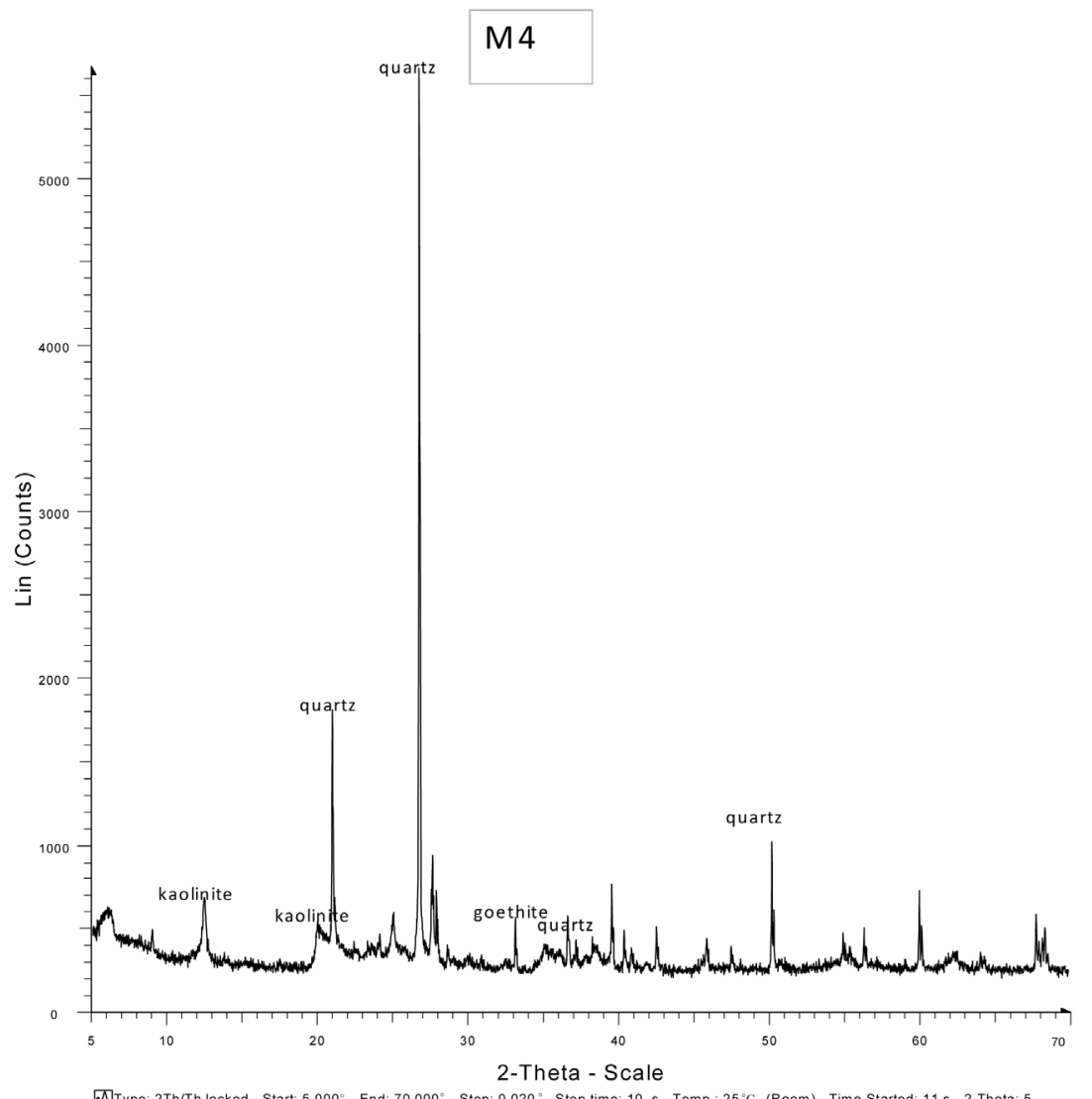

四Type: 2 Th/Th locked - Start: $5.000^{\circ}$ - End: $70.000^{\circ}$ - Step: $0.020^{\circ}$ - Step time: 10 . s - Temp: $25^{\circ} \mathrm{C}$ (Room) - Time Started: $11 \mathrm{~s}$ - 2 - Theta: 5

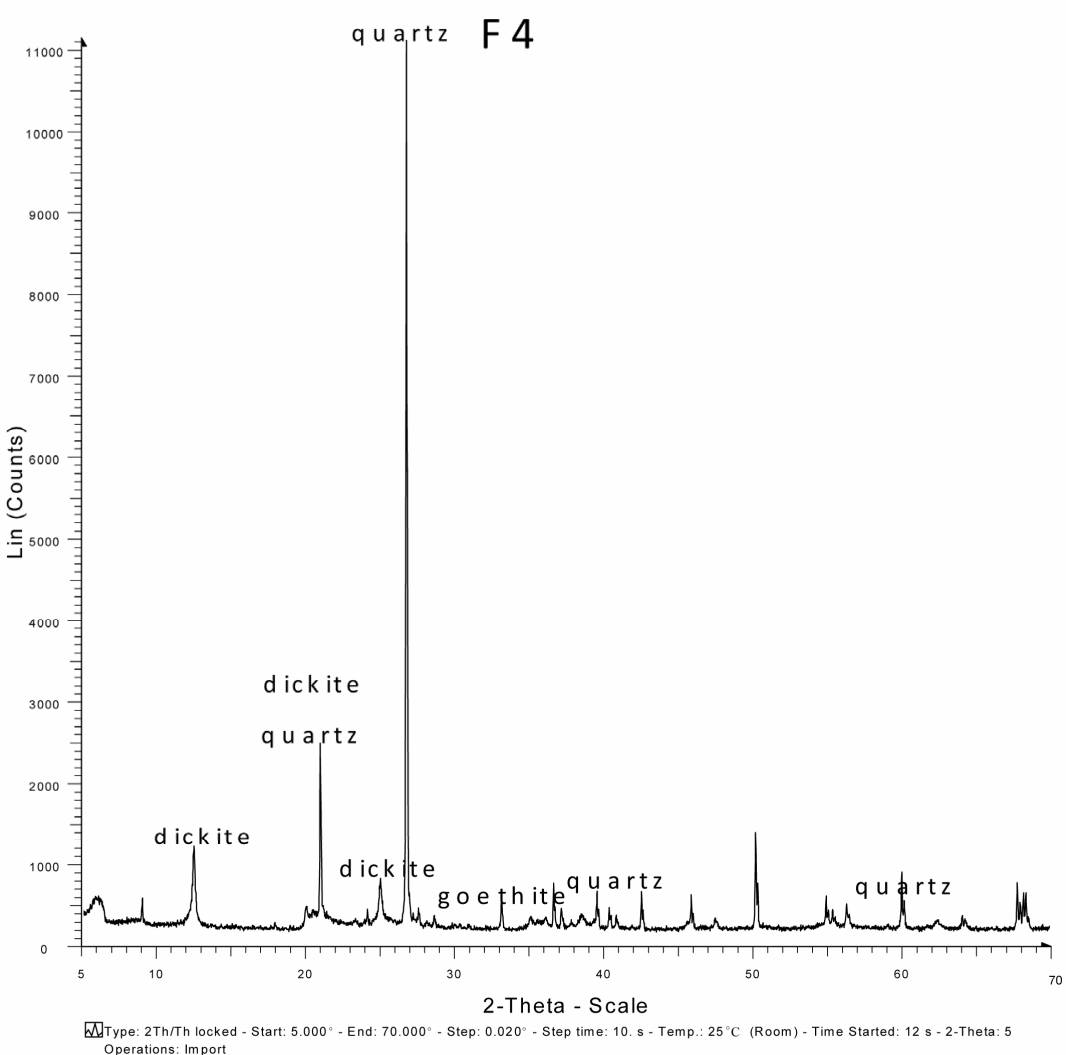

Figure 8. Identification of clay minerals present in samples K1, M1, M4 and F4. 


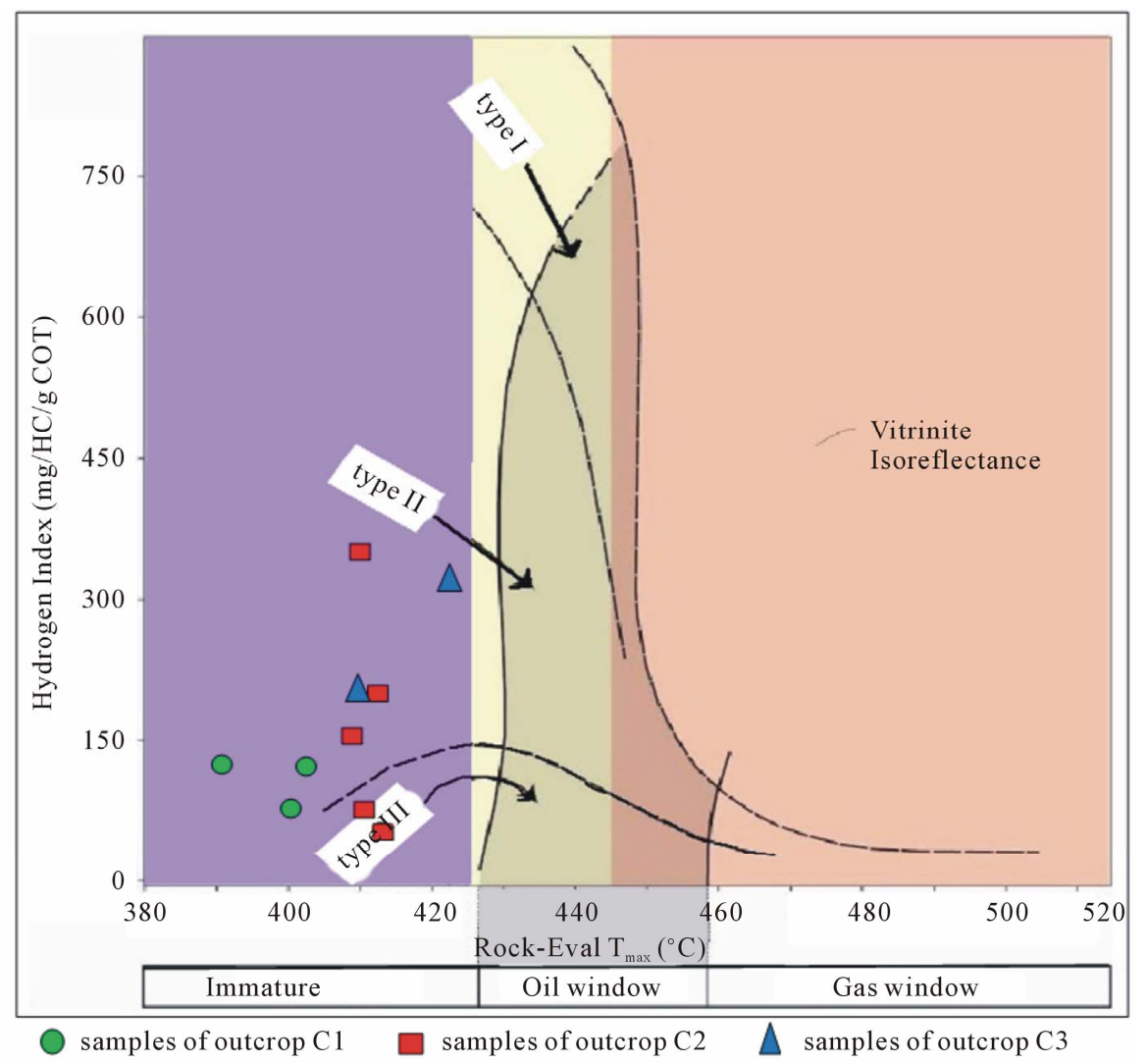

Figure 9. HI/ $\mathrm{T}_{\max }$ diagram showing the type and maturity level of organic matter for the samples studied.

Table 3. Geochemical parameters of samples of outcrop C3.

\begin{tabular}{|c|c|c|c|c|c|c|c|c|c|c|}
\hline Samples & $\begin{array}{l}\text { Depth } \\
\text { (m) }\end{array}$ & $\begin{array}{l}\mathrm{S} 1 \text { (mg hc/g } \\
\text { roche) }\end{array}$ & $\begin{array}{l}\mathrm{S} 2 \text { (mg HC/g } \\
\text { roche) }\end{array}$ & $\begin{array}{l}\mathrm{S} 3(\mathrm{mg} \mathrm{CO} / \mathrm{g} \\
\text { roche) }\end{array}$ & $\begin{array}{l}\mathrm{T}_{\max } \\
\left({ }^{\circ} \mathrm{C}\right)\end{array}$ & $\begin{array}{c}\mathrm{HI}(\mathrm{mg} \mathrm{HC} / \mathrm{g} \\
\text { TOC) }\end{array}$ & $\begin{array}{c}\mathrm{OI}\left(\mathrm{mg} \mathrm{O}_{2} / \mathrm{g}\right. \\
\text { TOC) }\end{array}$ & $\begin{array}{c}\text { TPI } \\
(\mathrm{S} 1 / \mathrm{S} 1+\mathrm{S} 2)\end{array}$ & $\begin{array}{c}\text { TOC } \\
\text { (\% pds) }\end{array}$ & $\begin{array}{l}\text { MINC } \\
(\%)\end{array}$ \\
\hline F2 & 21 & 2.27 & 3.84 & 0.22 & 423 & 326 & 19 & 0.37 & 1.18 & 0.16 \\
\hline $\mathrm{F} 4$ & 23 & 1.12 & 4.82 & 0.47 & 411 & 207 & 20 & 0.19 & 2.32 & 0.18 \\
\hline
\end{tabular}

\section{Discussion}

Petroleum source rocks are the primary component of the petroleum system [45] and constitute the precursors of oil and gas which, under favourable conditions, may ultimately migrate to reservoirs and be trapped to form accumulations. The TOC is the primary parameter in source rock appraisal, with a threshold of $1 \mathrm{wt} \%$ at the immature stage for potential source rocks $[46,47]$. The average value of $2.72 \%$ in the studied samples of outcrop C2, $1.75 \%$ in the studied samples of outcrop C3 and $1.51 \%$ in the studied samples of outcrop C1 exceeds this threshold. Such a value indicates a good to very good conditions for the preservation of organic matter which took place during deposition. This is certainly related to several factors all of which have contributed to the enrichment of organic matter. First of all, the productivity was probably high, as it is the case in the cretaceous clay deposits of the Douala sedimentary basin and the Ma- hakam delta [48] and the Maastrictian-Albian deposits of the Ivory Coast sedimentary basin.

Secondly, the conditions were probably anoxic in these environments as evidenced by the traces of partially decomposed organic matter. This can also be related to a high sedimentation rate which may have allowed a rapid burial of the sedimentary succession and the preservation of its organic matter content. It should be noted that this organic matter is immature (all IP values are greater than 0.1 though the $\mathrm{T}_{\max }$ values are less than $435^{\circ} \mathrm{C}$ ).

The second prerequisite for a good petroleum source rock is the quality of its organic matter. Bulk geochemical parameters obtained by Rock-Eval pyrolysis (S2, HI) show that with the exception of samples M1and M2 whose oil potential is good ( $5<\mathrm{S} 2>10)$, all the others S2 values are less than 5 indicating that the clay facies studied have a poor to fairly good oil potential. 
Samples M4 and F4 have a HI greater than 300 indicating that the organic matter was of marine origin. M2 and F2 have a HI value comprised between 150 and 300 meaning that the organic matter was a mixture of terrestrial and marine plants producing oil and gas. The rest of samples (K1, K2, K3, M1, M3 and M5) have a HI value below 150 indicating that the organic matter was from terrestrial origin made up of plants debris, thus generating gas.

All these portray geochemical characteristics of a poor to moderate petroleum source rock (Figure 7). But it is to notice that the quantity of hydrocarbon (oil and gas) is of interest for outcrop C2 and C3 since the mean S1 value is greater than $1 \mathrm{mg} \mathrm{HC} / \mathrm{g}$ of rock, and negligible for outcrop C1 (mean S1 < $1 \mathrm{mg}$ HC/g of rock).

Kaolinite present in samples studied is either of detrital or diagenetic origin. In the case of detrital origin, it results from hydrolysis of alkaline feldspars hihly represent in precambian rocks under humid and hot climate. In the case of diagenetic origin, kaolinite is the product of dissolution of potassic feldspars. The detrital origin for this study is expected because of permanent association of kaolinite with high quantity of quartz which is resistant to alteration and concentrate in sediments transported and deposited in sedimentary environments by rivers. The minerals results probably from weardering of Precambrian rocks of area surrounding the northern and eastern borders of Douala sub-basin. The presence of kaolinite indicates that the oil window has not been reach [49]. It then indicates the low degree of diagenesis (early diagenesis). The latter affects the surface sediments where the chemical properties of water are under control of the surface environment. The temperature during this phase can exceed $150^{\circ} \mathrm{C}$ and the depth not greater than 2 $\mathrm{km}$ [50]. The presence of dickite which is a polymorph of kaolinite and vaterite shows the increase in temperature (up to $250^{\circ} \mathrm{C}$ ) and pressure and consequently the degree of diagenesis (burying diagenesis) [51,52]. During this phase, compaction and thermal maturation of organic matter occur. Sample F4 which contains dickite has the highest thermal maturity temperature $\left(T_{\max }=423^{\circ} \mathrm{C}\right)$.

These characteristics are the same as those of (the petroleum potential here is globally poor) some source rocks of surrounding basins that were deposited under the same tectonic event (opening of the South Atlantic) but at a different period, namely:

The Kissenda Formation from the South and North Gabon basins consisting of organic shales interbeded with siltstones and carbonaceous shales. This formation contains mostly Type III or Type II/III kerogens and has an average TOC content of $1.5 \%-2 \%$ [31]. Reference [16] mentions that gas-prone source rocks are common in the Lower Cretaceous of the Mundeck formation (basal deposits of the Douala, Kribi/Campo basin), whereas oil-prone source rocks are rare. He found that in the Mundeck formation, TOC varies between 1\% and 3.5\% (four samples) and HI-values fluctuate from 100 to 200 mg HC/g TOC. Reference [53] identifies source rocks in four wells from the Kribi oil-field.

The oil potential of the samples studied is globally weak compared to those of the large majority of West Africa coastal basins [54]. Those are:

1) The Bucomazi Formation in the offshore Lower Congo and outer Kwanza basins of Angola contains Type I kerogens and displays a wide range of TOC percentages (5\% on average and up to $20 \%$ [55]. The upper unit of the Bucomazi Formation is less organic-rich (2\% 3\%) and contains Type I and Type II kerogens, although some organic-rich levels contain more than $10 \%$ TOC [56,57].

2) The Pointe Noire Formation and the upper part of the Djeno Formation of the north Congo basin contain Type I and Type II kerogens. The organic content fluctuates from $1 \%$ to $5 \%$, although some levels reach $20 \%$ TOC [58].

3) The Melania Formation of the offshore South Gabon sub-basin. The source rock consists of varved, pyritic shale and has an average TOC content of $6 \%$ and values as high as $20 \%$ have been measured [31]. Organic matter consists predominantly of Type I and intermediate Type I-II kerogens.

4) The "Serie des Schistes" in the Interior basin of Gabon, where the organic matter is related to Type II to I with TOC contents up to $22 \%$ [59].

5) A Kissenda-equivalent formation is found in the Rio Muni basin of Equatorial Guinea [39,60]. These facies constitute the regional primary source rock, consisting chiefly of algal kerogen with TOC contents as much as $6 \%$.

6) The lower Mundeck Formation around the Campo locality has a fair to good petroleum potential [55], although the organic-rich facies are thin and immature. The Lower Mundeck Formation along the coast is composed of thin organic-rich beds within sand dominated beds, but significant source potential could exist.

\section{Conclusion}

The dark to greyish clay of the Tertiary out croppings in Kompina, Miang and Fiko have been characterised for their oil potential using both Rock-Eval pyrolysis and $\mathrm{X}$ ray diffraction. The black to dark grey clay present a good concentration of organic matter (except K3, \%TOC $>1$ ). The HI versus $T_{\max }$ diagrams indicates that this organic matter did not experience high temperatures during burial. They did reach the thermal maturity of the oil window. This is confirmed by the presence of kaolinite, dickite and low quartz which are minerals of low tem- 
perature and constitute the most abundant in the samples studied. The studied samples then represent imamture organic-rich beds with a poor to fairly good oil potential, although samples M1 and M2 have a good petroleum potential up to $6.62 \mathrm{~kg} \mathrm{HC} / \mathrm{t}$ of rock and $6.44 \mathrm{~kg}$ $\mathrm{HC} / \mathrm{t}$ of rock respectively. The thickness and lateral extension of those beds most be evaluated. This would enable analyses on more samples and therefore to determine precisely the mean value of the petroleum potential of this part of the basin in view to correlate with the other parts of the Douala basin just as the other West African coastal basins.

\section{Acknowledgements}

This study was technically supported by PETROCI. Thanks go to the Director General for his helpful assistance in Rock-Eval analyses.

\section{REFERENCES}

[1] F. Solger, "Die Fossilien der Mungokreide in Kamerun und irhe Geologische Bedeutung,” Beitr. Geol. Kamerun, 1904, pp. 85-242.

[2] F. Solger, "Die petroleum funde am Mungo," Bohrtecniker Zeit, Wien, Vol. 11, No. 14, 1904, 12 p.

[3] S. F. Tamfu, M. Batupe, R. J. Pauken and D. C. Boatwright, "Geological Setting, Stratigraphy and Hydrocarbon Habitat of the Douala Basin, Cameroon," American Association of Petroleum Geologists Bulletin, Vol. 79, No. 13, 1995, p. 95.

[4] P. Menzel, "Fossile Pflanzenreste aus den Mungo-Schiten in Kamerun,” Abh. K. Preuss Geol. Landes., Neue Folge, Vol. 62, 1909, pp. 399-404.

[5] T. Vries, "Research Mission on Hydrocarbons in Cameroon Conducted between 1935-1936," General Report, Department of Mines, Cameroon, 1936, 72 p.

[6] E. Marchesini and B. Frasson, "Report on the Geological Survey of French Cameroon, December 1951-March 1952,” Standard Oil C, New Jersey, 1952, 14 p.

[7] D. Reyre, "Geological History of the Douala Basin (Cameroon)," Post-Cambrian Coastal Sedimentary Basins of West Africa, Part III, Micropaleontology Conference Dakar, African Association of Geological Services, Paris, 1964, 18 p.

[8] D. Reyre, “Geological History of the Douala Basin,” In: D. Reyre, Ed., Symposium on the Sedimentary Basins of the African Coast, African Association of Geological Services, IUGS, Paris, 1966, pp. 143-161.

[9] Y. C. Belmonte, "Stratigraphy of the Cameroon Sedimentary basin," Proceedings of the 2nd West African Micropaleontological Colloquium, Ibadan, 18 June-1 July 1966, pp. 7-24.

[10] M. Salard-Cheboldaeff, "Evidence of Oligocene in Cameroon Coastal Sedimentary Basin, According to Palynological Data,” Report of Science Academy, Series D, Paris, 1976, pp. 41-43.
[11] M. Salard-cheboldaeff, "Paléopalynology Cameroon Littoral Sedimentary Basin in Its Relations with the Stratigraphy and Paleoecology," $\mathrm{PhD}$ Thesis, Pierre and Marie Curie University, Paris, 1977, 262 p.

[12] M. Salard-Cheboldaeff, "Tertiary Pollens from Cameroon Reported to the Family Rubiaceae," Proceedings of the 6th African Micropaleontology Colloquium, Annual of Mines and Geology, Vol. 3, No. 28, 1980, pp. 279-289.

[13] P. R. N. Ngaha, "Contribution to the Geological, Stratigraphic and Structural Study of the Atlantic Border of Cameroon Sedimentary Basin,” PhD Thesis, University of Yaounde, Yaounde, 1984, 131 p.

[14] P. R. N. Ngaha and S. M. E. Belinga, "Evidence of Two Distinct Structural Domains in the Southwest of Cameroon Using the Photo-Interpretation Methods," Annals of the faculty of Science, Earth Science, Series IV, Vol. 1, No. 3-4, 1984, pp. 69-81.

[15] P. R. N. Ngaha and S. M. E. Belinga, “The Diachronism of the Basal Sandstone , Paleoenvironment and the Role of the Opening of the South Atlantic," Annals of the Faculty of Sciences, Earth Science, Series IV, Vol. 1, No. 3-4, 1987, pp. 103-119.

[16] R. J. Pauken, J. M. Thompson, J. R. Schuman and J. C. Cooke, "Geology of the Douala Basin, Offshore Cameroon,” Am. Assoc. Petr. Geol. Bull., Vol. 75, No. 3, 1991, pp. 651-652.

[17] W. C. Ackerman, D. C. Boatwright, B. M. Burwood, D. Van Lerberche, E. Bondjo, S. F. Tamfu and D. Ovono, "Geochemical Analysis of Selected Hydrocarbon Samples in the Douala Basin, Cameroon. Implications for an Oil-Prone Source Rock," American Association of Petroleum Geologists Bulletin, Vol. 77, No. 9, 1993, p. 1604.

[18] S. F. Tamfu, M. Batupe, R. J. Pauken and D. C. Boatwright, “Geological Setting, Stratigraphy and Hydrocarbon Habitat of the Douala Basin, Cameroon,” American Association of Petroleum Geologists Bulletin, Vol. 79, No. 13, 1995, p. 95

[19] P. R. N. Ngaha, "Palynostratigraphy and Reconstruction of the Cretaceous Paleoenvironments of the East of Douala Sedimentary Basin (Cameroon),” PhD Thesis, University of Yaounde I, Yaounde, 2005, 259 p.

[20] A. J. V. Garcia, "Paleogeographia de Nordeste Brasileiro no Jurassico Superior-Cretaceo Inferior," Geociensias, Vol. 10, 1991, pp. 37-56.

[21] S. R. Lawrence, S. Munday and R. Bray, "Regional Geology and Geophysics of the Eastern Gulf of Guinea (Niger Delta to Rio Muni)," The Leading Edge, 2002, pp. 1113-1117.

[22] F. R. Nguene, S. F. Tamfu, J. P. Loule and C. Ngassa, "Palaeoenvironments the Douala and Kribi/Campo SubBasins, in Cameroon, West Africa,” In: R. Curnelle, Ed., African Geology, 1st Colloquium on Stratigraphy and Paleogeography of West African Sedimentary Basins, 2nd Colloquium of African Micropaleontology, Libreville, 1991, Boussens, Elf Aquitaine, 1992, pp. 129-139.

[23] R. J. Pauken, "Sanaga Sud Field, Offshore Cameroon, West Africa,” In: M. T. Halbouty, Ed., Giant Oil and Gas Fields of the Decade 1978-1988, Am. Assoc. Petr. Geol. Mem., Vol. 54, 1990, pp. 217-230. 
[24] J. D. Hedberg, "A Geological Analysis of the Cameroon Trend,” PhD Dissertation, Princeton University, Princeton, 1969, 188 p.

[25] K. O. Emery, E. Uchupi, J. Phillips, C. Bowin and J. Mascle, "Continental Margin of Western Africa: Angola to Sierra Leone," American Association of Petroleum Geologists Bulletin, Vol. 59. No. 12, 1975, pp. 2209- 2265.

[26] J. M. Regnoult, “Cameroon Geological Synthesis,” Department of Mines and Geology, Yaounde, 1986, 119 p.

[27] T. J. A. Reijers and S. W. Petters, "Depositional Environments and Diagenesis of Albian Carbona tes on the Calabar Flank, SE Nigeria,” Journal of Petroleum Geology, Vol. 10, 1987, pp. 283-294. doi:10.1111/j.1747-5457.1987.tb00947.x

[28] J. Benkhelil, P. Giresse, C. Poumot and G. Ngueutchoua, "Lithostratigraphic, Geophysical and Morpho-Tectonic Studies of the South Cameroon Shelf," Marine and Petroleum Geology, Vol. 19, 2002, pp. 499-517. doi:10.1016/S0264-8172(02)00002-8

[29] A. H. Brink, "Petroleum Geology of Gabon Basin," AAPG Bulletin, Vol. 58, 1974, pp. 215-235.

[30] D. Reyre, "Remark on the Evolution of African Atlantic Coastal Sedimentary Basins," Bulletin of the French Geological Society, Vol. 36, 1984, pp. 1041-1059.

[31] P. Teisserenc and J. Villemin, "Sedimentary Basin of Gabon-Geology and Oil Systems,” In: J. D. Edwards and P. A. Santogrossi, Eds., Divergent/Passive Margin Basins, Vol. 46, American Association of Petroleum Geologists Mem 48, 1989, pp. 117-199.

[32] K. O. Emery, E. Uchupi, J. Phillips, C. Bowin and J. Mascle, "Continental Margin of Western Africa: Angola to Sierra Leone," American Association of Petroleum Geologists Bulletin, Vol. 59, No. 12, 1975, pp. 2209- 2265.

[33] J. H. Natland, "Composition, Provenance, and Diagenesis of Cretaceous Clasti Sediments Drilled on the Atlantic Continental Rise off Southern Africa, DSDP Site 361Implications for the Early Circulation of the South Atlantic/Nit,” Rep. DSDP 40, 1978, pp. 1025-1061.

[34] H. M. Bolli, et al., Init. Rep. DSDP 40, 1978, p. 1078.

[35] B. Tissot, G. Demaison, P. Masson, J. R. Delteil and A. Conbaz, "Paleoenvironment and Petroleum Potential of Middle Creataceous Black Shales in Atlantic Basin," AAPG Bulletin, Vol. 64, 1980, pp. 2051-2063.

[36] P. V. Zalan, E. P. Nelson, J. E. Warme and T. L. Davis, "The Piaui Basin: Rifting and Wrenching in an Equatorial Atlantic Transform Margin,” In: K. T. Biddle and N. C. Blick, Eds., Strike-Slip Deformation, Basin Formation, and Sedimentation: SEPM Spec. Pub. 37, 1985, pp. 177-192. doi:10.2110/pec.85.37.0177

[37] E. A. M. Koutsoukos, M. R. Mello, C. D. A. Filho, M. B. Hart and J. R. Maxwell, "The Upper Aptian-Albian Succession of the Sergipe Basin, Brazil: An Integrated Paleoenvironmental Assessment," AAPG Bulletin, Vol. 75, 1991, pp. 479-498

[38] E. Nyong and R. Ramanathan, "A Record of Oxygen Deficient Paleoenvironments in the Cretaceous of the Calabar Flank, SE Nigeria,” Journal of African Earth Sciences, Vol. 3, 1985, pp. 455-460.

\section{doi:10.1016/S0899-5362(85)80088-9}

[39] J. P. Turner, "Gravity-Driven Structures and Rift Basin Evolution: Rio Muni Basin, Offshore West Africa," American Association of Petroleum Geologists Bulletin, Vol. 79, No. 8, 1995, pp. 1138-1158.

[40] J. P. Turner, B. R. Rosendahl and P. G. Wilson, "Structure and Evolution of an Obliquely Sheared Continental Margin: Rio Muni, West Africa,” Tectonophysics, Vol. 374, 2003, pp. 41-55.

[41] M. J. Ntamak-Nida, S. Bourquin, J. C. Makong, F. Baudin, J. E. Mpesse, C. I. Ngouem, P. B. Komguem, and G. M. Abolo, "Sedimentology and Sequence Stratigraphy from Outcrops of the Kribi-Campo Sub-Basin: Lower Mundeck Formation (Lower Cretaceous, Southern Cameroon)," Journal of African Earth Sciences, Vol. 58, No. 1, 2010, pp. 1-18. doi:10.1016/j.jafrearsci.2010.01.004

[42] J. C. Dumort, "Explanatory Notice of the sheet Douala West. Geological Recognition Map at scale 1/500,000," Department of Mines and Geology, Cameroon, 1968, 69 p.

[43] J. B. Meyers, B. R. Rosendahl, H. Groschel-Becker, J. A. Austin and P. A. Rona, "Deep Penetrating MCS Imaging of the Rift-to-Drift Transition, Offshore Douala and North Gabon Basins, West Africa," Marine and Petroleum Geology, Vol. 13, No. 7, 1996, pp. 791-835. doi:10.1016/0264-8172(96)00030-X

[44] J. Espitalié, G. Deroo and F. Marquis, "La pyrolyse Rock Eval et ses applications,” Rev. l’Inst. Fr. Pet. 40, 1985, p. 755-784.

[45] L. B. Magoon and W. G. Dow, "The Petroleum System," In: L. B. Magoon and W. G. Dow, Eds., The Petroleum Sys- tem: From Source to Trap, American Association of Pe- troleum geologist Memoirs, Vol. 60, 1994, pp. 3-24.

[46] B. P. Tissot and D. H. Welte, "Petroleum Formation and Occurrence,” 2nd Edition, Springer-Verlag, Berlin, 1984, $699 \mathrm{p}$.

[47] M. L. Bordenave, “Applied Petroleum Geochemistry,” Editions Technip, 1993, 524 p.

[48] A. Riboulleau, "Geochemistry of Black Shales of the Upper Jurassic of the Russian Platform. Sedimentation and Preservation of Organic Matter," PhD Thesis, Paris VI University, Paris, 2000, 262 p.

[49] Y. Héroux, A. Chagnon and R. Bertrand, "Compilation and Correlation of Major Thermal Maturation Indicators," American Association of Petroleum Geologists Bulletin, Vol. 63, 1979, pp. 2128-2144.

[50] S. D Burley and H. R. Worden, "Sandstone Diagenesis: Recent and Ancient," John Wiley \& Sons, New York, 2003, 649 p.

[51] D. G. Segonzac, "The Transformation of Clay Minerals during Diagenesis and Low Grade Metamorphism: A Review,” Sedimentology, Vol. 15, 1970, pp. 281-346. doi:10.1111/j.1365-3091.1970.tb02190.x

[52] V. D. Shutov, A. V. Aleksandrova and S. A. Losievskaya, "Genetic Interpretation of the Polymorphism of the Kaolinite Group in Sedimentary Rocks,” Sedimentology, Vol. 15, 1970, pp. 69-82. doi:10.1111/j.1365-3091.1970.tb00206.x 
[53] M. E. Ndonwie, "Petrophysical Characterization of Petroleum Reservoirs and Source Beds of the Batanga SubBlock, Kribi-Campo Sub-Basin, Cameroon,” AAPG Annual Convention, Abstract, 2007, 1 p.

[54] M. J. Ntamak-Nida, F. Baudin, J. Schnydern, J. C. Makong, P. B. O. Komguem and G. M. Abolo, "Depositional Environments and Characterization of the Organic Matter of the Lower Mundeck Formation (Barremian-Aptian) of the Kribi-Campo Sub-Basin (South Cameroon): Implications for Petroleum Exploration,” Journal of African Earth Sciences, Vol. 51, 2008, pp. 207-219. doi:10.1016/j.jafrearsci.2008.01.006

[55] M. A. Pasley, E. N. Wilson, V. A. Abreu, M. G. P. Brandao and A. S. Telles, "Lower Cretaceous Stratigraphy and Source Rock Distribution in Pre-Salt Basins of the South Atlantic. Comparison of Angola and Southern Brazil," American Association of Petroleum Geologists Bulletin, Vol. 82, No. 10, 1998, p. 1949.

[56] S. E. Brice, M. D. Cochran, G. Pardo and A. D. Edwards, "Tectonics and Sedimentation of the South Atlantic Rift Sequence, Cabinda, Angola,” In: J. S. Watkins and C. L. Drake, Eds., Studies in Continental Margin Geology, American Association of Petroleum Geologist Memory,
Vol. 34, 1982, pp. 5-18.

[57] N. B. Schoellkopf and B. A. Patterson, "Petroleum Systems of Offshore Cabinda, Angola,” In: M. R. Mello and B. J. Katz. Eds., Petroleum Systems of South Atlantic Margins, Am. Assoc. Petr. Geol. Mem., Vol. 73, 2000, pp. 361-376.

[58] S. Baudouy and C. Legorjus, "Sendji Field-People’s Republic of Congo, Congo Basin,” In: N. H. Foster and E. A. Beaumont, Eds., Treatise of Petroleum Geology, Atlas of Oil and Gas Fields-Structural Traps V: Tulsa, Okla, Am. Assoc. Petr. Geol., 1991, pp. 121-149.

[59] M. M. Mounguengui, F. Baudin, J. Lang and O. Jocktane, "Paleoenvironments and Characterization of Oil Source Rocks of Pre-Saliferous Series of the Interior of Gabon Basin,” Report of the Academy of Science, Paris, 2003, pp. 327-334.

[60] J. P. Turner, "Detachment Faulting and Petroleum Prospectivity in the Rio Muni Basin, Equatorial Guinea, West Africa,” In: N. R. Cameroon, R. H. Bate and V.-S. Clure, Eds., The Oil and Gas Habitats of the South Atlantic, Vol. 153, Geological Society Special Publications, 1999, pp. 303-320. 